\title{
Expectancy as a Mediator of the Relation between Learning Strategies and Academic Achievement among University Students
}

\author{
Orhideja Shurbanovska \\ Institute of Psychology, Faculty of Philosophy, \\ University "St. Cyril and Methodius", Skopje, Macedonia1
}

\author{
Biljana Blazhevska-Stoilkovska \\ Institute of Psychology, Faculty of Philosophy, \\ University "St. Cyril and Methodius", Skopje, Macedonia
}

\begin{abstract}
The aim of this study was to explore the mediation role of the expectancy component of motivation (self-efficacy and control beliefs for learning) in the relationship between learning strategies (cognitive, meta-cognitive, resource management strategies) and academic achievement. The sample consisted of 155 university students (85 psychology students and 70 architecture students). Learning strategies section from the MSLQ (Motivated Strategies for Learning Questionnaire) was taken to assess the extent of learning strategies usage during exam preparation. Motivation for learning was measured by the Expectancy scale as a part of the Motivation section of the MSLQ. Mediation analysis was used for data processing. Following the proposed steps for mediation effect testing, a series of regression analyses was conducted: first, the expectancy component of motivation was regressed on learning strategies; second, academic achievement was regressed on learning strategies; and third, academic achievement was regressed on the expectancy component of motivation. It was found that learning strategies influence academic achievement indirectly through the expectancy component of motivation (Sobel test=2.18; $\mathrm{p}=.029$ ). It is emphasized that students should be encouraged to use learning strategies in knowledge acquisition.
\end{abstract}

Key words: learning strategies, expectancy component of motivation, academic achievement, mediation analysis

The importance of students' proactive behaviour in the learning process attracts more attention nowadays. It involves self-initiating and controlling of learning, i.e. applying self-regulated strategies in the acquisition of new

1 e-mail: surbanovska@yahoo.com 
knowledge (Loranger, 1994, as cited in Young, 2005). Self-regulated learning is based on complex psychological processes, as thinking, concluding, judgment, analyzing, synthesizing and categorizing. It presupposes that students use old knowledge and experiences to understand the new material better and easier, that they combine data from different sources in a logical/ meaningful manner, and that they make conclusions and solve problems independently. According to Zimmerman (2002), proactive or self-regulated learning is based on self-awareness, self-motivation and learning strategies to implement knowledge appropriately. Niemivirta (1999, as cited in VizekVidović et al., 2004) suggests that self-regulatory learning includes learning strategies, self-efficacy, goal orientation and self-esteem.

Accordingly, this research is focused on learning strategies and motivation as aspects of self-regulated learning and their role in academic achievement.

Learning strategies denote deliberate planning and monitoring of cognitive and affective processes that are involved in the successful completion of academic tasks (Corno \& Mandinach, 1983, as cited in Young, 2005). The best known as well as the simplest learning strategies that help keep the information in the long-term memory comprise repetition, organization, and elaboration. Repetition means uttering the text without attempting to process it deeper (deeper thinking and linking the elements of the same task and with the other tasks). This type of learning strategy is used when something needs to be learned by heart in order, for example, to achieve a better grade. Organization of learning materials supports the gestalt principle that well-organized information is easier to learn. One of the ways to organize the material is to form internal connections, which establishes a hierarchy among the key information (for example, classifications in biology, chemistry). Organization, as a learning strategy, is used for schemes when students want to organize a larger amount of material into a coherent unit. Schemes are types of plans that are learned and then applied. If a piece of information is entered into the scheme then it can be memorized more easily. Elaboration is the process of expansion of new information by adding or connecting the learning content with what is already known. Elaboration is usually combined with different mnemonic techniques.

According to Pintrich (1999), there are three basic types of learning strategies: cognitive, meta-cognitive and resources management strategies. Cognitive strategies refer to students' use of basic and complex strategies for information processing (repeating the words, paraphrasing, summarizing, outlining, creating tables, applying previous knowledge in new situations, critical evaluation). Meta-cognitive control strategies involve helping students in regulating their own cognition (planning, monitoring and modifying). Resource management includes managing one's time and study environment, as well as regulating one's efforts, learning with peers and seeking help from peers and teachers. 
Niemivirta (1999, as cited in Vizek-Vidović et al., 2004) distinguishes between three categories of learning strategies. The first is the deep processing strategy, based on students' interest in the learning content. Its purpose is to understand the material and discover the deeper meaning. The second learning strategy is referred to as surface processing, where students' learning efforts are only aimed at achieving a goal (for example, good grades). The student generally only tries to remember what she/he learned without thinking. The third strategy is self-hindering, in which students do not invest effort in learning and their failure is attributed to less learning, not to the lack of ability. Namely, the cognitive and metacognitive learning strategies in Pintrich's model are closely related to the strategies of superficial and deep processing of the learning material, stated in Niemvirta's model. Their connection is in the sustaining role of Pintrich's cognitive and meta-cognitive strategies in deep processing of the content which is to be learned. Students try to understand and find a deeper meaning of the content by analyzing, summarizing, categorizing and similar cognitive processes in learning. Or, if students use surface processing (Niemvirta's learning strategies), they usually use strategies such as repeating the words, remembering and similar cognitive strategies in recipient learning (Pintrich's types of learning).

Motivation as a driving force for students' learning goals, the activities in which they engage in order to reach the goals and the intensity with which they engage in these activities (Rothstein, 1990; Woolfolk, 1990; as cited in Young, 2005), is the other important factor in the process of learning, in addition to the types of learning strategies. It unites a number of sources that reinforce intellectual activities. Accordingly, motivation is referred to as a complex construct with many components. One of them is the expectancy component, which refers to students' beliefs that they can accomplish a task, the confidence in their own skills and beliefs that outcomes are contingent upon their own effort, rather than external factors such as the teacher or luck (Garcia\&Pintrich, 1995). Clearly, this motivational component incorporates two constructs, self-efficacy beliefs and perceived control (locus of control), which are strongly related (Zimmerman, 2000).

Pintrich and his colleagues (Pintrich\&Garcia, 1991; Pintrich, Smith, Garcia \& McKeachie, 1993, as cited in Garcia\&Pintrich, 1995) reported that motivation, cognitive, meta-cognitive strategies and resource management were positively associated, while anxiety was negatively associated with course grades among students. A significant positive correlation between grade point average and deep processing (meta-cognitive strategy) and a significant negative correlation between grade point average and disorganization were reported by Elliot, McGregor and Gable (1999). Garcia and Pintrich (1995) found that $39 \%$ of variance in the grades of the computer and natural science students and $17 \%$ of variance in the grades of the social science, humanities 
and foreign languages students was explained by motivation and learning strategies; self-efficacy was one of the best predictors of course grades. In another study, Pintrich and De Groot (1990) found that 22\% of variance in the average grade was explained by motivational and learning strategies variables; significant predictors were self-efficacy and self-regulation. They also found that self-efficacy beliefs were positively related to cognitive and self-regulation learning strategies. Consequently, these authors stressed that integration of learning strategies and motivational beliefs into unique model was necessary. The study conducted by Zimmerman and Martinez-Pons (1990) revealed similar findings: the perceptions of verbal and mathematical efficacy were positively correlated with learning strategies use (verbal self-efficacy was highly correlated with strategy use compared to mathematical self-efficacy). The conclusion is that self-efficacy leads to use of some learning strategies.

There is an opinion that the relation between self-efficacy and learning strategies is reciprocal. The use of learning strategies also increases selfefficacy beliefs (Zimmerman, 2002; Zumbrun, Tadlock \& Roberts, 2011), but more research on this link is needed (Pintrich, 1999).

Taking into consideration the afore-mentioned, the aim of the present research was to set a model where learning strategies (cognitive, metacognitive and resource management strategies as a unique variable) predict students' expectancy motivation (self-efficacy and control beliefs for learning) which, in turn, influences their academic achievement. More precisely, it was explored how learning strategies relate to academic achievement when the expectancy component of motivation was included as a mediation variable.

Earlier empirical findings show that the expectancy component of motivation, along with the value component of motivation in Pintrich's model of motivation, most strongly relate to academic achievement. Also, this component incorporates self-efficacy beliefs as a construct that is closely linked to learning strategies. This is why this motivation component (expectancy) was taken as a variable in the research.

It was hypothesized that learning strategies positively and indirectly relate to academic achievement through an association with the expectancy component of motivation.

\section{Method}

\section{Sample}

The sample consisted of 155 university students (55\% were psychology students and $45 \%$ were architecture students). Sixty-nine students were in their second year of studies (mean age 19) and 86 students were the fourth/ final year of studies (mean age 22). The majority of subjects (110) were female, while 45 were male. 
The sample was heterogeneous considering study programs and the year of study. Considering the fact that studying psychology and architecture requires different learning strategies, on the one hand, and that the beginning and the end of the studying period brings different academic success expectations on the other, they were controlled statistically in our research.

\section{Instruments}

The learning strategies section from MSLQ - Motivated Strategies for Learning Questionnaire (Pintrich, Smith, Garcia \& McKeachie, 1991) was taken to assess the extent of learning strategies usage during exam preparation. This section included three general scales: a) the cognitive strategies scale with 19 items, b) the meta-cognitive strategies scale with 12 statements and c) the resource management scale with 11 items. The responses were assessed on a 7-point Likert scale from 1 (not at all true of me) to 7 (very true of me). The author states that these scales can be used together or separately. Accordingly, for the purpose of this study, the sum of three scale scores was used to represent learning strategies as a whole. The higher total score stood for the higher degree of learning strategies usage. Cronbach alpha reliability for the cognitive, meta-cognitive and resource management scales, as well for the learning strategies scale as a whole, was $0.88,0.73,0.78$ and 0.92 , respectively.

Motivation for learning was measured by the Expectancy scale as a part of the Motivation section of the MSLQ. It consists of 12 statements that assess self-efficacy for learning and beliefs that success in that process is contingent upon their own effort. The answers were given on a scale from 1 (not at all true of me) to 7 (very true of me). The higher score denoted the higher degree of motivation for learning. Reliability (Cronbach alpha) for this scale was 0.82 .

The questionnaire was modified in order to measure learning strategies and the expectancy component of motivation (self-efficacy and control believes) in terms of their presence in the studying process in general, not in particular courses. Rotgans and Schmidt's (2010) study confirmed that MSLQ could be used at the general curriculum level.

Academic achievement was represented as an arithmetic mean of all grades (ranging from 6 to 10) that students obtained on exams they had passed until the last exam session before the survey (the autumn session, 2010).

\section{Procedure}

Data were collected in October 2010 during students' regular classes. It was explained that participation in this study was voluntary, that responses would remain confidential and only used for research purposes. All students 
present at the classes agreed to participate. The questionnaire was completed in approximately 20 minutes.

\section{Statistical analysis}

Meditation analysis was used for data processing. According to Baron and Kenny (1986), this analysis is based on three criteria that must be upheld: 1) the independent variable must predict the dependent variable; 2) the independent variable must predict the mediation variable; 3 ) the mediation variable must be a significant predictor of the dependent variable. This method, named the causal steps strategy, is commonly used in this kind of mediation analysis (Preacher\&Hayes, 2008).

Following the proposed steps for mediation effect testing, a series of regression analyses was conducted. First, academic achievement (i.e. the dependent variable) was regressed on learning strategies (i.e. the independent variable) to estimate their relation. Second, the expectancy component of motivation (i.e. the mediator) was regressed on learning strategies (i.e. the independent variable) to test the association between these two variables. Third, academic achievement was regressed on the expectancy component of motivation to test whether these variables were related, as well as on learning strategies to estimate their relationship when the mediator was entered into the regression model.

In all regression analyses, the study group (psychology and architecture students) and the year of study (second and fourth) were controlled for.

\section{Results}

The basic statistics and zero-order correlations between study variables are presented in Table 1.

Table 1. Means, standard deviations and zero-order correlations between study variables $(\mathrm{N}=155)$

\begin{tabular}{ccccccccc}
\hline & Min. Max. & M & SD & \multicolumn{3}{c}{$\begin{array}{c}\text { Zero-order } \\
\text { correlations }\end{array}$} \\
& & & & & & & \\
& & & & & 1 & 2 & 3 \\
\hline 1. Learning strategies & 2.53 & 6.32 & 4.67 & .78 & - & $.40^{* *}$ & $.22^{\star *}$ \\
2. Expectancy component of motivation & 3.38 & 6.88 & 5.46 & .77 & & - & $.28^{\star *}$ \\
3. Academic achievement & 6.00 & 9.90 & 7.66 & .92 & & & - \\
\hline
\end{tabular}

${ }^{\star} \mathrm{p}<.05 ;{ }^{\star *} \mathrm{p}<.01 ;{ }^{\star * *} \mathrm{p}<.001$

As can be seen, the mean of learning strategies usage $(M=4.67)$ was close to the midpoint of the measurement scale (from 1 to 7), i.e. students used Pintrich's learning strategies to a moderate extent. The mean of the expectancy component of motivation $(\mathrm{M}=5.46)$ was relatively high compared to the 
midpoint of the scale (from 1 to 7 ), which implies that students had relatively high expectations regarding their academic success. The mean of academic achievement was lower than eight, which means that students had a below average academic achievement. These three variables were positively and significantly correlated with each other. Namely, the students who frequently used learning strategies during studying had stronger expectations of academic success and a higher academic achievement as well.

Table 2 presents the findings of mediation hypothesis testing.

Table 2. Summary of the mediation test for predicting academic achievement

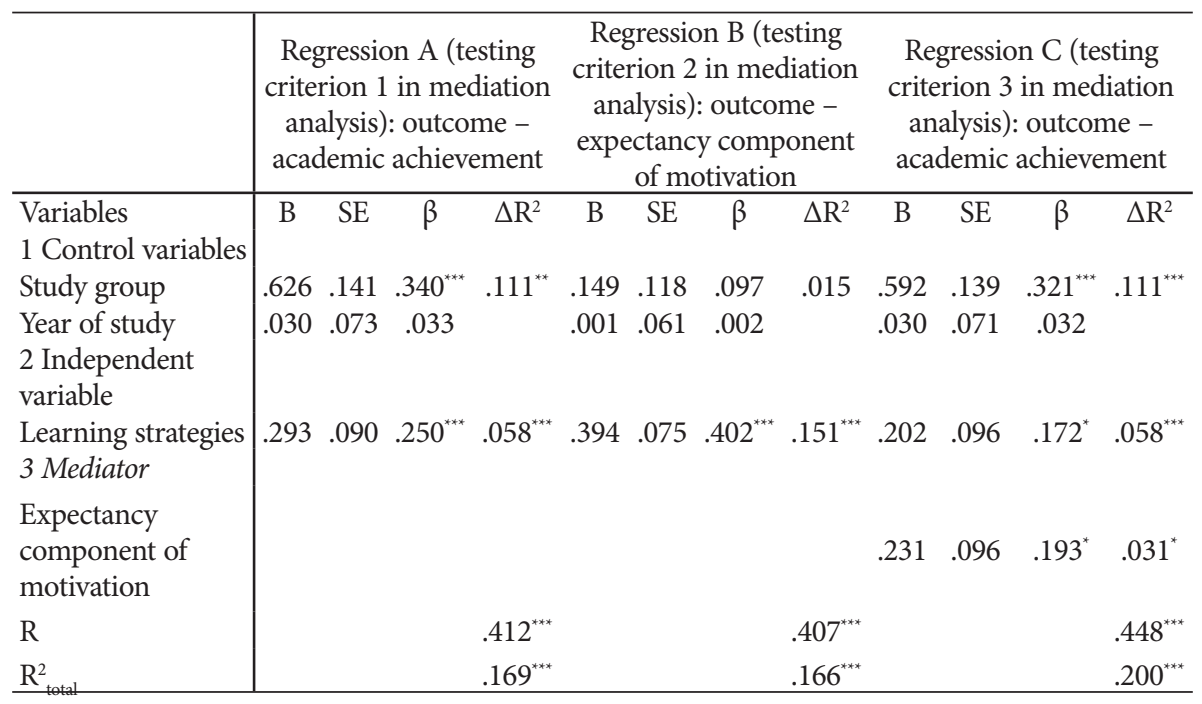

The results of Regression analysis A (Table 2) showed that the control variable study group accounted for $11.1 \%$ of the variance in the academic achievement $(\mathrm{F}(2,152)=9.504, \mathrm{p}<.001)$. The average academic success was higher among psychology students than among architecture students $(\beta=$ $.340 ; \mathrm{p}<.001)$. Learning strategies explained a significant $5.8 \%$ in the variance of academic achievement $(\mathrm{F}(1,151)=10.602, \mathrm{p}<.001)$. These two variables were positively and significantly related $(\beta=.250 ; \mathrm{p}<.001)$. Therefore, criterion 1 in mediation analysis was met.

In Regression analysis B (Table 2), learning strategies were positively associated with the expectancy component of motivation $(\beta=.402 ; \mathrm{p}<.001)$. This variable significantly accounted for $15.1 \%$ of the variance in the mediator $(\mathrm{F}(1,151)=27.331, \mathrm{p}<001)$. Accordingly, criterion 2 in mediation analysis was met. Control variables did not contribute significantly to explaining the variance in the expectancy component of motivation.

As can be noted from Regression analysis C (Table 2), when the study group and year of study were controlled for, learning strategies and the 
expectancy component of motivation were significant predictors of academic achievement $(\beta=.172 ; \mathrm{p}<.05$ and $\beta=.193 ; \mathrm{p}<.05$, respectively). The amount of explained variance in academic achievement was $8.9 \%$. Namely, the mediator variable added a significant $3.1 \%$ in the variance of the respondents' academic achievement $\mathrm{F}(1,150)=5.816, \mathrm{p}<.05)$.

It is shown that the prediction strength of learning strategies declines (the standardized regression coefficient in Regression $\mathrm{C}$ is lower than the standardized regression coefficient in Regression A). This result was in line with criterion 3 in mediation analysis.

Sobel test was used to test the mediation effect. It was confirmed that indirect effect of learning strategies on academic achievement through the expectancy component of motivation was significant (Sobel test $=2.18 ; \mathrm{p}$ $<.05$ ). According to this result, the expectancy component of motivation partially mediated the relationship between learning strategies and academic achievement.

\section{Discussion}

The aim of this study was to examine how learning strategies (cognitive, meta-cognitive and resource management strategies together as a unique variable) relate to academic achievement when the expectancy component of motivation (self-efficacy and control beliefs for learning) was included as mediation variable.

The findings showed that the use of learning strategies increased selfefficacy and control beliefs for learning, which confirmed their proposed link (Zimmerman, 2002, Zumbrun, Tadlock \& Roberts, 2011).

The positive association between learning strategies and academic achievement, as well as between the expectancy component of motivation and academic achievement, are consistent with previous research (Elliot, McGregor \& Gable, 1999; Garcia \& Pintrich, 1995; Pintrich \& De Groot, 1990; Pintrich \& Garcia, 1991; Pintrich et al., 1993, as cited in Garcia \& Pintrich, 1995). Caprara and his colleagues (2011) suggested that junior high-school grades contributed to academic self-efficacy beliefs at the age of 16, which, in turn, contributed to high-school grades, over and above the effects of socioeconomic status and prior academic achievement.

The results speak in favour of the assumption that learning strategies increase self-efficacy beliefs which, in turn, leads to higher academic achievement. Namely, it was found that the mediation effect of the expectancy component of motivation on the relationship between learning strategies and academic achievement is partial. These findings indicated that when university students used learning strategies in exam preparation, or in other words, when they used paraphrasing, summarizing, outlining, critical evaluation, planning, monitoring, modifying and regulated their own efforts, 
when they learned with their colleagues and sought help from colleagues and teachers, they became more confident in their self-efficacy and control over the learning process and learning outcomes. This, in turn, increased their academic achievement.

The exploration of the path between learning strategies, expectancy and academic achievement contributes to an enlargement of empirical findings on their relations. It can be pointed out that students need to be encouraged to manifest self-regulated learning in knowledge acquisition. Additionally, the situations where they can develop their skills to self-initiate and self-control learning process should be created. In that way, their self-efficacy beliefs and perceived control over learning could become stronger. Finally, their academic success is expected to increase. Research findings suggested that effective strategies to develop self-regulated skills included monitoring and imitation of models, as teachers, parents, coaches, peers (Zimmerman, 2002; Schunk, 1981, as cited in Zimmerman, 2000). Other proposed strategies comprise direct instructions (Zimmerman, 2008), social support and feedback (Labuhn, Zimmerman \& Hasselhorn, 2010). Finally, this study has demonstrated that learning strategies and the expectancy component of motivation explained approximately $10 \%$ of variance in academic achievement.

This result suggests that other factors contribute to academic achievement, such as cognitive abilities (general and specific intelligence), some personal traits (openness and conciseness), previous experience and socio-economic status. Previous studies have shown a medium to strong relation between the socio-economic status and achievement (Selcuk, 2005). Students who belong to families with higher socio-economic status are usually more motivated for learning because they live in stimulating conditions (their parents have a higher level of education, they have a positive attitude towards studying and are provided with all they need for studying). According to Eccles and Wiegfeld's pattern of expectation of success, positive beforehand studying experience influences the expectancy of a higher academic success, and vice versa. Namely, the expectation of success is determined by three factors: beforehand experience in similar situations, interpretation of the causes of success or failure and perception of the difficulty of a particular task (VizekVidović et al., 2003).

Bandura's (1997) social cognitive theory provides guidelines for enhancing students' expectation of success, managing their educational development and regulating their learning activities. Those techniques can be applied as a basis for many interventions aimed at enhancing students' academic achievement, as well as to promote life-long learning.

Future research should also include high school students. There is a need to explore the mediation role of other motivation components such as extrinsic and intrinsic goals, interests, perceived usefulness of the material. Prior experiences and social context should be taken into consideration, too. 


\section{References}

Bandura, A. (1997). Self-efficacy: The exercise of control. USA: W.H. Freeman and Company.

Baron, R. M. \& Kenny, D. A. (1986). The moderator-mediator variable distinction in social psychological research: Conceptual, strategic, and statistical considerations. Journal of Personality and Social Psychology, 51 (6), 1173-1182.

Elliot, A. J., McGregor, H.A. \& Gable, S. (1999). Achievement goals, study strategies and exam performance: A mediation analysis. Journal of Educational Psychology, 91 (3), 549-563.

Caprara, G. V., Vecchione, M., Alessandri, G. Gerbino, M., Barbaranelli, C. (2011). The contribution of personality traits and self-efficacy beliefs to academic achievement: A Longitudinal study. British Journal of Educational Psychology, 81,78-96.

Garcia, T. \& Pintrich, P.R. (1995). Assessing students' motivation and learning strategies: The motivated strategies for learning questionnaire. Paper presented at the Annual Meeting of the American Educational Research Association, San Francisco, CA, April, 18-22, 1995.

Labuhn, A. S., Zimmerman, B. J. \& Hasselhorn, M. (2010). Enhancing students' selfregulation and mathematics performance: The influence of feedback and selfevaluative standards. Meta-cognition and learning, 5 (2), 173-194.

Pintrich, P. R. (1999). The role of motivation in promoting and sustaining selfregulated learning. International Journal of Educational Research, 31, 459-470.

Pintrich, P. R. \& De Grott, E. V. (1990). Motivational and self-regulated learning components of classroom academic performance. Journal of Educational Psychology, 82 (1), 33-40.

Pintrich, P. R., Smith, D. A. F., Garcia, T. \& McKeachie, W. J. (1991). A manual for the use of the Motivated strategies for learning questionnaire (MSLQ). School of Education Building, University of Michigan, Ann Arbor, Michigan.

Preacher, K. J. \& Hayes, A. F. (2008). Asymptotic and resembling strategies for assessing and comparing indirect effects in multiple mediator models. Behavior Research Methods, 40 (3), 879-891. doi: 10.3758/BRM.40.3.879

Rotgans, J. I \& Schmidt, H. G. (2010). The Motivated strategies for learning questionnaire: A measure for students' general motivational beliefs and learning strategies? The Asia-Pacific Education Research, 19 (2), 357-369.

Selcuk, R.S. (2005). Socioeconomic status and academic achievement: A metaanalytics review of research. Review of Educational Research, 75 (3), 417-453.

Vizek-Vidović, V., Štetić, V. V., Rijavec, M. \& Miljković, D. (2003). Psihologija obrazovanja. Zagreb: IEP, VERN.

Young, M. R. (2005). The motivational effects of the classroom environment in facilitating self-regulated learning. Journal of Marketing Education, 27 (1), 25-40. doi: $10.1177 / 0273475304273346$

Zimmerman, B. J. (2000). Self-efficacy: An essential motive to learn. Contemporary Educational Psychology, 25, 82-91. doi: 10.1006/ceps.1999.1016

Zimmerman, B. J (2002). Becoming a self-regulated learner: An overview. Theory into practice, 41 (2), 64-70. 
Zimmerman, B. J. (2008). Investigating self-regulation and motivation: Historical background, methodological developments and future prospects. American Educational Research Journal, 45 (1), 166-183.

Zimmerman, B. J. \& Martinez-Pons, M. (1990). Student differences in self-regulated learning: relating grades, sex and giftedness to self-efficacy and strategy use. Journal of Educational Psychology, 82 (1), 51-59.

Zumbrun, S., Tadlock, J. \& Roberts, E. P. (2011). Encouraging self-regulated learning in the classroom: A review of the literature. Metropolitan Educational Research Consortium (MERC), Virginia Commonwealth University.

DATUM PRIHVATANJA RADA: 16.05.2013.

\section{Očekivanje kao posrednik u odnosu između strategija učenja i akademskog postignuća kod studenata}

\section{Orhideja Shurbanovska}

Institut za psihologiju, Filozofski fakultet, Univerzitet „Sv. Ćirilo i Metodije”, Skoplje, Makedonija

\section{Biljana Blazhevska-Stoilkovska \\ Institut za psihologiju, Filozofski fakultet, Univerzitet „Sv. Ćirilo i Metodije”, Skoplje, Makedonija}

Tema rada je medijaciona uloga motivacione komponente očekivanja (samoefikasnosti i uverenja o kontroli pri učenju) u odnosu između strategija učenja (kognitivnih, metakognitivnih i strategija za upravljanje resursima) i akademskog postignuća. Uzorak je obuhvatio 155 studenata (85 studenata psihologije i 70 studenata arhitekture). Za procenjivanje stepena primene strategija učenja tokom pripreme ispita korišćen je deo o strategijama za učenje iz MSLQ upitnika (Motivated Strategies for Learning Questionnaire). Motivacija za učenje merena je skalom očekivanja koja je deo sekcije o motivaciji u MSLQ. U obradi podataka korišćena je medijacijska analiza. U skladu s predloženim koracima za testiranje posrednih efekata, sproveden je niz regresivnih analiza: prvo, strategije učenja posmatrane su kao prediktor motivacione komponente očekivanja; drugo, strategije učenja posmatrane su kao prediktor akademskog postignuća; i treće, motivaciona komponenta očekivanja korišćena je kao prediktor akademskog postignuća. Pokazuje se da strategije učenja indirektno utiču na akademsko postignuće preko motivacione komponente očekivanja (Sobel test=2.18; $\mathrm{p}=.029$ ). Ističe se da studente treba podsticati da koriste strategije učenja u usvajanju znanja.

Ključne reči: strategije učenja, motivaciona komponenta očekivanja, akademsko postignuće, medijacijska analiza. 